\title{
Is Bank Creditworthiness associated with Risk Disclosure Behavior? Evidence from Islamic and Conventional Banks in Emerging Countries
}

\author{
Rihab Grassa \\ LIGUE-ISCAE, University of Manouba-Tunisia \\ Higher Colleges of Technology- UAE \\ rihab_grassa@hotmail.fr \\ Nejia Moumen \\ Tunis Business School, University of Tunis \\ LIGUE-ISCAE, University of Manouba, Tunisia \\ nejia.moumen@tbs.rnu.tn \\ Khaled Hussainey \\ Portsmouth Business School, Portsmouth University, \\ United Kingdom \\ khaled.hussainey@port.ac.uk
}

\begin{abstract}
We investigated if banks with higher risk disclosure scores benefitted from higher credit ratings relative to banks with weaker risk disclosure scores. Also, we investigated if Islamic banks could exert positive effects on their credit ratings. By employing a sample of 169 banks observed over the period from 2009 to 2014 and after controlling for bank-specific risk characteristics, we documented banks with high credit rating scores were keen to preserve an upper level of credit risk transparency when compared to banks with lower credit ratings. Moreover, the positive association between credit rating and risk disclosure is more pronounced for conventional banks than for Islamic banks. When compared to conventional banks, Islamic banks disclose less risk information due to the risk nature of their businesses, which affect in turn their credit ratings.

\section{Keywords}

Credit rating; conventional banks; risk disclosure; Islamic banks; ownership structure 


\section{Introduction}

Credit Rating Agencies (CRAs) provide opinions on the creditworthiness of entities and on their abilities to honor future financial obligations. Indeed, market participants rely heavily on their ratings in financing and in investment decision-making. Accordingly, this makes them a key player in channeling resources within capital markets. Therefore, Credit Rating Agencies (CRAs) play a vital information and valuation role by reducing the information asymmetry between capital providers and issuers and through influencing stock returns and bond pricing (Elbannan, 2009). In this role, CRAs collect and analyze information relevant to assessing a firm's perceived risk and credit quality. The rating process incorporates public and private information and builds upon forecasted future cash flows in order to assess a firm's long-run ability to meet its debt obligations (Standard and Poor's, 2009). Thereafter, they make their results of these analyses widely available to investors, portfolio managers, buy-side firms, sell-side firms, and others (Frost, 2016).

During the recent financial crisis, CRAs have been the focus of international attention and have been subject to substantial criticism due to their prominent role in the global financial instability. As a result of the regulatory changes in banks' capital requirements and risk management processes, they continue to occupy an influential place in the financial architecture. Following Basel II, credit ratings can be used to assign the risk weights and to set minimum capital charges for different categories of borrowers (Frost, 2016). Basel II considers, also, banks' disclosures about their inherent risks to be a vital element of an effectively supervised, safe and sound banking system. Since timely and accurate risk information provides an important foundation for financial stability, CRA analysts consider the risks to which banks are exposed and the techniques that banks use to identify, measure, monitor and control the quality of their credit assessment.

The importance of CRAs has fueled extensive research on rating determinants. Previous literature (e.g., Lev and Penman, 1990; Welker, 1995; Dhaliwal et al., 2011; He, 2018) suggests that corporate disclosure, either quantitative or qualitative, is an instrument through which managers may influence credit ratings. Accordingly, financial reporting has implications for long-term streams of firms' future earnings and reduces information asymmetry. 
For this reason, financial information reduces the uncertainty of whether or not a firm follows through with its plans; reduces rating agencies' estimation risk about its future prospects; and, in turn, increases its perceived creditworthiness (e.g. Bozanic and Kraft, 2014; Kraft, 2015; Basu, Naughton and Wang, 2017; Bonsall and Miller, 2017;).

Despite the growing interest in the interaction between credit rating and corporate disclosure behavior in the financial marketplace (e.g. Bozanic and Kraft, 2014; Oh and Park, 2017; Bonsall and Miller, 2017; Naughton, Basu and Wang, 2017; He, 2018), little attention has been paid on whether and how banks' transparency about their risk profile influence rating analysts' assessments of their credit worthiness and viability. As previous studies suggest, CRAs tend to disagree more about the evaluation of banks' credit risks than about their credit risk measurements of other sectors (Cantor and Parker, 1996; Morgan, 2002 and Packer and Tarashev, 2011). This is because "the assessment of a bank's asset quality is both the most important and the most difficult element of bank analysis.... The analyst must exercise then his or her judgment using what can only be impressionistic information..." (Moody's Special Comment, 1993; p.3). This is an important omission. Indeed, market practitioners, such as the Financial Stability Board, 2012 and PWC, 2013) highlight the importance of improving banks' risk reporting on the stability of the banking sector. The enhancement of investors' understanding of banks' risk exposures and risk management practices, by improving the quality of risk disclosures, may reduce uncertainty premiums and contribute to wider financial stability and, more especially, for well-managed firms. In turn, this can influence the firms' credit rating.

By using a sample of 169 banks observed over the period from 2009 to 2014, we investigate whether banks with higher risk disclosure scores benefit from higher credit ratings relative to banks with weaker risk disclosure scores. Also, we investigate if, when compared to conventional banks, Islamic banks benefit from higher creditworthiness. We focus on emerging economies for two main reasons. First, most Islamic banks operate in emerging markets. Second, little attention has been devoted to the creditworthiness of banks operating in emerging economies which are characterized by high uncertainty, low disclosure quality and a restoration of interest in the current global capital markets.

Our findings provide evidence that: 
(1) There is a positive association between credit ratings and risk disclosure behavior.

(2) When compared to conventional banks, Islamic banks have lower credit ratings.

(3) When compared to conventional banks, on average Islamic banks disclose slightly less risk information.

(4) When compared to younger and non-listed banks; leveraged, older and listed banks have lower credit ratings.

(5) Foreign ownership and block holders have negative effects on the banks' credit ratings.

(6) Tier 1 ratio has a positive effect on the banks' credit ratings.

(7) When compared to conventional banks, the impact of risk disclosure has a stronger effect on the Islamic banks' credit ratings.

This study contributes to the existing literature in the following ways. We give a new insight into the economic consequences of risk disclosure by introducing the impact of rating analysts' perceptions. Indeed, since credit ratings reflect how banks are valued in capital markets, we investigate if risk information can be an important determinant of the rating process and may better outline the usefulness of that information for market participants. Further, we examine if the unique features, associated with either conventional or Islamic banks, in emerging markets, affect the relationship between credit ratings and risk disclosure. We argue that, combined with their capital structure and governance attributes, the unique nature of banks assets creates fundamental uncertainty for investors and analysts. Uncertainty over bank risk is inherent to some extent and this is likely to be reduced by banks' risk disclosure. Indeed, nowadays, several of international, national governmental and private rating agencies are working on enhancing the credit rating methodology for both Islamic and conventional banks. In this regard, this study's findings can be useful for those organizations as they revise and update their assessment methods.

The remainder of the paper is organized as follows. Section 2 discusses the literature review and develops the research hypotheses. Section 3 describes our sample and sources of data; defines 
the variables; and provides descriptive statistics. Section 4 presents the empirical models used to investigate the relationship between credit ratings and banks' risk disclosure along with the main empirical results. In section 5, we conduct robustness checks. In section 6, we state our conclusions and offer suggestions for future researches.

\section{Literature Review and Development of Hypotheses}

\subsection{The Credit Rating Process and Risk Information}

Credit analysts are sophisticated users of financial information. Their primary task is to gather, process and, eventually, uncover private information about borrowers. They transform that information into ratings which can be shared and interpreted easily by capital providers (Bozanic and Kraft, 2014). The underlying rating process relies on hard accounting information and related financial ratios to form an opinion about a firm's credit worthiness. Although these accountingbased measures are essential when assessing the solvency of that particular entity, they do not fully explain the credit rating procedure. A series of papers (Dietrich and Kaplan, 1982; Stein, 2002; Campbell and Loumioti, 2013; Bozanic and Kraft, 2014; Campbell et al., 2017) suggest that some of the information relevant to rating debt\# commitments is qualitative, such as narrative disclosure, and its credit relevance requires credit analysts to make a "judgment call" by. According to the signaling theory and resource dependence theory, these disclosures are likely to contain incremental information that predicts future performance. This information has the potential to influence analysts' judgments of credit risk throughout the firms' lives as well as for those in distress (Mayew et al.,2015; Bozanic, Roulstone and Buskirk al.,2018). For example, Bozanic and Kraft (2014) show that, when firms provide more disclosures pertaining to credit risk and debt, credit rating analysts are more likely to make soft adjustments that reflect increases in credit risk. Further, they indicate that, when managers provide more earnings-related and forward-looking disclosures, CRA analysts are more likely to make soft adjustments that reflect reductions in credit risk.

In relation to the banking system, ElAmer (2017) argues that banks' common performance metrics are not the sole source of information used by independent analysts. They are likely to refer to the myriad of banks' characteristics such as management quality, capital adequacy, asset 
quality, risk management, growth prospects, efficiency, and internal control processes. Indeed, Standard and Poor's claims that the extent of information risk influences the level of the rating and, in cases of extreme information risk, if a rating is assigned (Standard and Poor's, 2009).

There is little previous evidence about the economic consequences of risk disclosures with respect to banks' credit ratings.

The closest existing studies are those of Skaife, Collins and LaFond (2006); Aman and Nguyen (2013); Chan et al. (2013); DeBoskey and Gillett (2013) and Kuang and Qin (2013). Their findings demonstrate a positive relationship between the quality of voluntary disclosure and banks' credit ratings. More recently, ElAmer's (2017) findings show a positive relationship between banks' risk disclosure and their credit ratings and suggest that improved risk disclosure is a means used by managers to reduce the information asymmetry and to signal to the market the bank's quality and future prospects. This can facilitate its access to critical resources. As such, we argue that risk disclosures may complement the information that credit analysts obtain from traditional quantitative inputs (e.g. profitability, cash flow, leverage, etc.). CRA analysts are likely to be concerned with managerial assessments of firms' credit risks and outlooks which we capture from a disclosure perspective.

Therefore, we developed the following first hypothesis:

H.1: Risk disclosure has a positive effect on banks' credit ratings.

\subsection{Banks' Feature and Risk Disclosure: Islamic Banks versus Conventional Banks}

Islamic banks are institutions that perform all the typical functions of financial intermediation while retaining their Islamic character. They mobilize funds from household savings through a range of deposit products and channel these funds into shariah compliant projects. Unlike conventional banking which relies fully on man-made principles and uses the interest rate mechanism to operate, Islamic banking embraces the Islamic law fully and uses the profit/loss sharing for purposes of financial intermediation. The basic rules, which govern the of Islamic banks' operations, can be reviewed as follows: 
(i) Islamic banks are forbidden to conduct interest-based (riba) transactions.

(ii) Islamic banks are not allowed to participate in uncertainty (gharar) or speculation.

(iii) Islamic banks are proscribed from sinful financing and socially irresponsible activities

(e.g. weapons, pork, gambling).

(iv) Islamic banks adhere to profit risk-sharing.

(v) Islamic banks use tangible assets as collaterals in financial transactions (Radzi and Lonik, 2016).

The significant differences in the operational philosophies of conventional and Islamic banking have resulted in Islamic banks being challenged with risks that are comparable to those borne by conventional banks and with risks that stem exclusively from Shariah considerations (Ahmed and Khan, 2007; Dar, Azeem and Masood, 2013; Radzi and Lonik, 2016). First, Islamic banks should guarantee always that their transactions and products are consistent with Shariah principles. Failure to comply with such principles results in the transaction being rejected and this can lead to fiduciary risk (Ahmed and Khan, 2007).

A failure to maintain fiduciary responsibilities results, in turn, in a reputational risk that, eventually, can cause a withdrawal of funds. Second, the absence of interest-based (riba) transactions has caused far more serious liquidity risks to Islamic banks as compared to their conventional counterparts. Indeed, Islamic banks are unable to raise funds quickly from the markets given the restrictions on their interest-based operations, the constraints on the securitization of the existing assets and the slow development of financial instruments (Radzi and Lonik, 2016). Third, the specific characteristics of Islamic financial contracts result, also, in Islamic banks facing higher operational risks as compared to conventional banks. Since Shariahcompliant products rely on the idea of profit and loss and, thus, risk-sharing, Islamic banks are unable in certain cases to alleviate credit risk by requiring collateral from clients. This is because their relationship is established on a partnership basis. Moreover, they do not have enough control over the management of projects financed in the form of Mudarabah. It follows that the risk may result from the quality of the partner, the underlying business activities and the moral hazard issues. Finally, Islamic banks are confronted further by displaced commercial risk. The 
Accounting and Auditing Organization of Islamic Financial Institutions (AAOIFI) describes displaced commercial risk as the risk incurred when an Islamic bank faces pressures to pay its investors and depositors a rate of return higher than what should be payable under the "actual" terms of the contract. Such risk suggests that, while such banks may operate in full compliance with Shariah requirements, they may be unable to pay competitive rates of return when compared to those other Islamic banks and competitors. Consequently, the bank foregoes part or its entire share-profit model in order to retain its fund providers and to avoid the risk of their withdrawing their funds (Radzi and Lonik, 2016; Abedifar, Molyneux and Tarazi,2017).

As a consequence of these specific risks inherent in Islamic banking, several papers (e.g. Errico and Farahbakhsh, 1998; Dignah, Latiff, and Rahman, 2012) point out that prudential supervision and regulations governing Islamic financial institutions should place a greater emphasis on operational risk and on high standard of risk disclosure. For instance, we posit that, when compared to their conventional counterparts, Islamic banks are required to be more transparent and accountable. One way, used by Islamic banks to show greater accountability and transparency, is to engage in increased disclosure about their risk profiles.

Disclosure can be an effective instrument for Islamic banks through which management can influence credit ratings. Due to the risk-sharing character of Islamic finance, risk disclosure is such an instrument in that it has long-term implications for an Islamic bank's current and future risk management practices and helps to reduce information asymmetry.

A firm's creditworthiness is determined by assessing the likelihood that its future cash flows will be enough to cover debt service costs and principal payments (Skaife et al. 2006). International private rating agencies claim to have incorporated information transparency into the assessment of a firm's creditworthiness. Therefore, in order to increase their credit rating scores, Islamic banks are likely to disclose more information regarding their risk management practices and plans. Hence, risk disclosure can reduce the uncertainty if an Islamic bank will meet its obligations in full and on time. Thereby, it will reduce rating agencies' estimation risk in respect to an Islamic bank's future cash flow and, in turn, will increase the CRAs' perceptions of a bank's creditworthiness. 
Since Islamic banks are more risky than conventional banks, we expect that the effect of risk disclosure on banks' credit ratings is more pronounced for Islamic banks than conventional banks. Therefore, we developed the following second hypothesis:

H.2: The positive effect of risk disclosure on Banks' credit ratings is more pronounced for Islamic banks when compared to their conventional counterparts.

\section{Research design:}

\subsection{Sample and data}

Our paper investigates the economic consequences of risk disclosure through the lenses of market expectations for a sample of conventional and Islamic banks in twelve emerging countries. We consider the extent of risk related information at an aggregated level since embracing international rules regarding risk disclosure and the credit rating process in emerging markets is a cornerstone to their steady integration into the global financial system. Indeed, eight of our twelve investigated countries have either required or at least permitted their listed financial firms to use IFRS. The literature on the financial sector shows further that, when compared to firms in other industries, banks disclose more risk information and have different features (e.g. Capital Adequacy, Asset Quality, Management, Earnings, Liquidity, and Sensitivity to Market Risk) inherent in the CRAs' judgement about their credit worthiness [e.g. Nier and, Baumann, 2006; Hirtle, 2007; Pérignon and Smith, 2010; Al-Hadi et al, 2017]. This is without mentioning that most Islamic banks in Bahrain, Jordan, Qatar, Saudi Arabia or Malaysia are required either to comply or to move toward embracing the AAOIFI and IFSB standards at a smooth pace.

Our study uses annual data from 2009 to 2014. Our sample consists of bank-year observations in which the data on all variables including credit ratings are available and risk disclosure information is released at least once. For each bank-year sample, we matched the frequency of risk disclosure in the corresponding year with the credit ratings and control variables at the end of the previous year. 
We collected credit-rating data from the three internationally different credit rating agencies, namely Moody's Investor Services, Standards and Poor's and Fitch, and we used their creditrating grades credit-rating agencies. When a firm's credit rating differed across these agencies, we chose the lowest grade.

We collected other data from several sources. These were, namely, banks' annual reports, banks' financial statements, Bankscope, Zawya database (formally Zawya database), World Bank, the investigated countries' stock exchanges and the banks' websites.

Our final sample consists of 1014 bank-year observations. We study Islamic banks and conventional banks separately; 582 observations apply to conventional banks and the 432 observations apply to Islamic banks.

\subsection{Empirical model}

We used the following model to examine the impact of risk disclosure on a bank' credit rating:

$$
\text { RATING }_{i ; t 1}=f\left(\mathrm{RD}_{i, t} ; \text { Control Variables } i ; t-1\right)
$$

Where RATING is the credit rating assigned by a rating agency to bank $i$ in year $t$ and $R D_{i, t}$ is the score of risk disclosure provided by bank i in year $\mathrm{t}$.

We discuss below these variables and the control variables.

\subsubsection{Measure of Credit Rating}

Given the information asymmetry between firms and bondholders in the capital market, CRAs play a critical role in influencing bondholders' investment decisions. Credit rating reflects the CRAs' evaluation of a firm's willingness to pay its financial obligations in full and on time.

Our dependent variable is the bank credit rating (RATING). This reflects the CRAs' assessment of the obligator's credit worthiness with respect to its senior debt obligations. We used the longterm issuer credit ratings compiled by the CRAs' service. The ratings range from AAA (highest rating) to $D$ (lowest rating-debt in payment default). For the purposes of our analysis, we collapsed the multiple ratings into seven categories as per the schedule detailed in Table 1. Many previous studies have used this method (Skaife, Collins and Lafond, 2006; Alali, Anandarjan, and 
Jiang, 2012 and Grassa 2014). In order to facilitate the discussion of the economic significance of our results, we used, also, a two-category classification scheme-investment grade and speculative grade to estimate our logistic regression model using. Table 1 shows the assignment of the credit rating groups into these two classifications.

Table 1: Credit Rating Classifications

\begin{tabular}{lc}
\hline Debt rating & Assigned RATING score \\
\hline Aaa & 7 \\
Aa+ & 6 \\
Aa & 6 \\
Aa- & 6 \\
A+ & 5 \\
A & 5 \\
A- & 5 \\
Baa + & 4 \\
Baa & 4 \\
Baa- & 4 \\
Ba+ & 4 \\
Ba & 3 \\
Ba- & 3 \\
B+ & 3 \\
B & 2 \\
B- & 2 \\
Caa + & 2 \\
Caa & 1 \\
C & 1 \\
\hline
\end{tabular}

\subsubsection{Measure of Risk Disclosure}

Our study uses the content analysis approach to evaluate banks' risk disclosure across different jurisdictions. This is the most common and widely used method in corporate disclosure literature (e.g. Beretta and Bozzolan, 2004; Linsley and Shrives, 2006; Abraham and Cox, 2007; Deumes, 2008; Amran, Bin, and Hassan, 2009; Dobler, Lajili, and Zeghal, 2011; Elzahar and Hussainey, 2012). Weber (1990, p117) defines content analysis as "a research method that uses a set of procedures to make valid inferences from text". 
Weber (1990) argues further that the rules, applied throughout this inferential process, vary depending on the analyst's interest. According to the context, such technique enables a replicable and valid inference from data (Krippendorff, 1980).

In order to ensure the replicability of inference, our content analysis involves the following three broad steps:

(a) development of an appropriate coding scheme that lists the expected risk items likely to be disclosed in the banks' annual reports;

(b) coding of the texts of the narrative disclosure sections; and

(c) conversion of data into quantitative measures of risk disclosure.

We discuss each step below in more detail.

We chose to focus on banks' annual reports for several reasons. Their annual reports provide a myriad of financial and non-financial information. They discuss, among other things, the bank's activities and performance, their governance structure, their capital resources' management and the material risks to which they are exposed. As Brown and Tucker. (2011) suggest, narrative disclosures in the form of qualitative and forward-looking information complement the historical financial information; increase the overall quality of annual reports; and have considerable value for the bank's stakeholders.

We developed an appropriate coding scheme that listed broad categories and the different risk factors related to these categories. We based the coding scheme on several relevant sources such as e.g.:

- $\quad$ The guidelines of the International Financial Reporting Standard (IFRS) 7;

- The Basel II: Market Discipline guideline;

- The AAOIFI and IFSB standards (specific to Islamic banks); and

- The accounting literature (Cabedo and Tirado, 2004; Oliveria, Rodriques and Craig, 2011; Barakat and Hussainey, 2013; Abdallah et al, 2015; Nahar, Azim and Jubb, 2016).

Our risk assessment instrument combines the banks' most significant risk categories, namely, capital structure, financial risk, operational risk, financial instruments, reserves, segment 
information, accounting and presentation policies and general risk information and the two risk categories specific to Islamic banks. In total our risk disclosure checklist covers 69 items grouped into 8 risk categories.

An essential element of content analysis is the selection of the unit of analysis. The use of either word, sentence or area of page as a measurement unit is commonplace. In order to serve the purpose of our study and to be consistent with recent risk disclosure literature (Beretta and Bozzolan, 2004; Linsley and Shrives, 2006; Abraham and Cox, 2007; Amran, Bin, and Hassan., 2009; Dobler, Lajili, and Zeghal, 2011; Oliveira, Rodriguez and Craig, 2011; Hussainey and Elzahar, 2012; Moumen, Ben Othman and Hussainey, 2015; 2016) we used the sentence as a unit scale.

We believe that sentences are far more reliable and meaningful than other units of analysis (Milne and Adler,1999; Linsley and Shrives, 2006). We allocate to each of our risk factors the number of risk related sentences provided in the banks' annual reports.

We code risk disclosures in every sentence that gives an insight into "any opportunity or prospect, or of any hazard, danger, harm, threat or exposure, that has already impacted or may impact upon the company, as well as the management of any such opportunity, prospect, hazard, harm, threat, or exposure" (Linsley and Shrives, 2006, pp.389).

We ensure the construct validity of our risk factors checklist and the reliability of our coding process through several rules and procedures. First, as outlined previously, we derived the index categories and related items from a wide range of sources of information (IFRS, Basel II, AAOIFI, IFSB, risk disclosure literature). Second, we used one single coder to perform the content analysis of banks' annual reports (Krippendorff, 2004). Third, an independent reviewer with financial reporting expertise coded a sub sample of 25 annual reports to ensure the reliability of the scale. Krippendroff $(1980 ; 2004)$ believes it is essential that at least two coders do each analysis separately and compare their results for purposes of reliability.

Fourth, we compared the risk disclosure grid coded by both scholars (the main researcher and the independent reviewer) to ascertain if there were any significant discrepancies through the Krippendorff's alpha reliability test (Hayes and Krippendorff, 2007; Krippendorff, 2010). The test generated a Kalpha of 0.825 which, for this intra-class agreement coefficient, was a satisfactory 
level of inter-rater reliability. Basically, a K-alpha, which is equal to 0.80 , is a cut off point for a good reliability test that has a minimum of 0.67 (Krippendorff, 2004).

\subsubsection{Control Variables}

The control variables involve time-varying firm characteristics that are expected to affect credit rating based on the previous research in the field. Previous studies provide evidence that there is a positive association between firm size and profitability associated with credit rating while losses, leverage and firm age have negative effects on the credit rating. Other studies provide evidence that larger firms and firms with lower debt have better ratings. Foreign ownership and blockholders are expected, also, to induce more risk disclosure because managers may be willing to reduce monitoring costs, caused by foreign ownership, through voluntary disclosure and, hence, this has a positive effect on the credit ratings (Horrigan, 1966; Kaplan and Urwitz1979, Skaife, Collins, and Lafond, 2006; Grassa 2015; Oh and Park, 2017; Al Alali et al, 2012). For country-level control, we used two variables: namely, GDP and Business extent of disclosure index. Previous studies highlight the positive effect of GDP on credit rating Afonso, 2003; (Boumparisa, Milasa and Panagiotidis, 2017;), and the positive effect of the business extent disclosure index on the firm's level of disclosure (Grassa and Chakroun, 2016; Grassa, Chakroun and Husseiney, 2018; Grassa, El-Halaby and Husseiney 2019). Therefore, we expect that these two variables affect the bank's credit rating.

Table 1-A below summarizes the definition of each variable and the expected signs of its relationships with corporate disclosure. 
Table 1-A: Model Specification and Measurement of Variable

\begin{tabular}{|l|l|l|c|}
\hline \multicolumn{1}{|c|}{ Variable } & \multicolumn{1}{|c|}{ Full Name } & \multicolumn{1}{c|}{ Variable description } & Expected sign \\
\hline ROA & Return on assets & Net income/total assets & $(+)$ \\
\hline LIST & Listed bank & $\begin{array}{l}1 \text { if the bank is listed in the stock } \\
\text { exchange, 0 otherwise }\end{array}$ & $(+)$ \\
\hline BANKSIZE & Bank size & Natural logarithm of total assets & $(+)$ \\
\hline BKAGE & Bank age & Number of years & $(-)$ \\
\hline LEVERAGE & Leverage & Long-term debt/ total assets & $(+)$ \\
\hline FOREIGN & $\begin{array}{l}\text { foreign } \\
\text { ownership }\end{array}$ & $\begin{array}{l}\text { Percent of shares owned by foreign } \\
\text { shareholders }\end{array}$ & $(-)$ \\
\hline BLOCK & blockholders & Number of blockholders & $(+)$ \\
\hline TIER 1 & Tier 1 Capital & $\begin{array}{l}\text { Natural logarithm of Gross domestic } \\
\text { products }\end{array}$ & $\begin{array}{l}\text { domestic } \\
\text { products }\end{array}$ \\
\hline GDP & $\begin{array}{l}\text { Business extent of } \\
\text { disclosure index }\end{array}$ & $\begin{array}{l}\text { The index ranges from 0 to 10, with } \\
\text { higher values indicating more } \\
\text { disclosure. }\end{array}$ & $(+)$ \\
\hline COUTRANSDEX & 1 if it is an Islamic bank, 0 Otherwise & \\
\hline Islamic & Islamic &
\end{tabular}

For the purpose of testing Hypothesis 1, the following regressions are estimated to be:

RATING $_{i, t}=\beta_{0}+\beta_{1}$ RD $_{i, t}+\beta_{2}$ ROA $_{i, t}+\beta_{3}$ LIST $_{i, t}+\beta_{4}$ BANKSIZE $_{i, t}+\beta_{5}$ BANKAGE $_{i, t}+\beta_{6}$ LEVERAGE $_{i, t}+\beta_{7}$

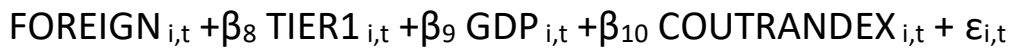

This regression tests if there is a significant association between banks with higher credit ratings and greater risk disclosure (i.e. $\beta 1>0$ ).

For the purpose of testing Hypothesis 2, related to the strength of the relationship between risk disclosure and credit rating, we divided our sample into Islamic and conventional banks subsamples. The impact of risk disclosure on credit rating is expected to be stronger for Islamic banks as compared to conventional banks. More particularly, in relation to the interested coefficients, $\beta 1$ we tested, through the regression (1) if there were more significant estimations for Islamic banks than for the conventional banks. 


\section{Results}

\subsection{Sample Statistics}

\section{Insert Table 2A and Table 2B here}

Table 2A presents for both Islamic and conventional banks the distribution of the credit ratings of all available bank-year observations. The Table reveals that the ' $A$ ' grade is a suitable cut-off level to distinguish if a bank is evaluated highly in the market. Among the total available 565 bank-year observations, 282 observations (49.91\%) have a credit-rating grade equal to or greater than ' $A$ '. $53.95 \%$ of these banks are Islamic and the other $46.05 \%$ are conventional banks.

Table 2B describes the distribution of the credit ratings for both Islamic and conventional banks per countries. The highest risk disclosure score is observed for Malaysia and the lowest in Tunisia.

\section{Insert Table 3 here}

Table 3 illustrates the statistics of the risk disclosure variable and its sub index across various credit ratings for the entire sample, the Islamic banks' sample and the conventional bank subsamples. The summary of the full sample's risk disclosure statistics indicates a wide distribution of risk disclosure within the sample. A preliminary idea of the association between risk disclosure and the credit rating can be obtained by looking at the mean value of risk disclosure across the credit rating grades. Table 3 shows, also, that, on average and when compared to conventional banks, our sample of Islamic banks disclose more risk information for credit rating grades $\mathrm{A} a \mathrm{a}$ and $\mathrm{Aa}$ and less for credit ratings between Caa and A (which covering the majority of our banks' samples). Our finding is consistent with previous studies. Abdallah et al.'s (2015) findings show that Islamic financial institutions, which operate in the GCC countries, disclose less corporate risk than their non-Islamic peers. Indeed, since Islamic financial principles are more conservative than those governing conventional banks, Islamic banks' financial products serve the interests of society more widely than conventional banks that are more likely 
to be oriented to the pursuit of profit maximization. However, Islamic banks are less engaged in reporting risk than their conventional counterparts. Ariffin, Archer and Abdel Karim's (2007) findings show that Islamic banks' transparency is more pronounced than in conventional banks due to their profit- sharing arrangements. Nevertheless, Islamic banks are still deficient in their risk disclosure.

\section{Insert Table 4 here}

Table 4 reports the descriptive statistics in respect of our samples. On average, most of the banks, which constitute our sample, have an " $\mathrm{A}$ " credit rating. It is noteworthy that the Islamic banks' credit ratings are slightly higher than the conventional banks' average credit ratings. Our finding is consisting with Grassa (2015).

Our sample's average score of risk disclosure is 438 . On average, when compared to Islamic banks, conventional banks disclose slightly more about risk. Our finding is consisting with those of Abdallah et al. (2015) and Grassa, Moumen and Husseiney (2018). Table 4 shows, also, that, on average, Islamic banks have higher percentages of foreign ownership, lower numbers of blockholders and, when compared to conventional banks, are on average larger, younger and have greater Tier 1 ratios.

\section{Insert Table 5 here}

Table 5 reports the outputs of the correlation matrix of the covariates used in the analysis. It is apparent that there are no significant correlation coefficients greater than $50 \%$ and, therefore, our estimation is not subject to the multicollinearity problem. 


\section{Regression Results: Ordered Logit Results}

\section{Insert Table 6 here}

In this paper, we employ the same methodology as used by Skaife et al. (2006) and Grassa (2015). Our empirical test results are derived from a general model that represents credit rating as a function of bank characteristics, risk disclosure and ownership structure.

In order to test the predicted relationship between risk disclosure and credit ratings, we estimate an ordered logit model. We use ordered logit because the seven categories of credit ratings convey ordinal risk assessments. In this regard, we can rank banks' preferences in respect of each of the categories but we cannot assume uniform differences in benefits (costs) between the categories.

Table 6 presents the results of our estimated models. Model 1 tests the overall model for the entire sample. Models 2 and 3 have tested respectively the Islamic banks' subsample and the conventional banks' subsample. Our three models are highly significant with a likelihood ratio of $\mathrm{X}^{2}$ varying from 78.358 to 107.98 with a generalized $\mathrm{R}^{2}$ varying between 0.349 and 0.443 . These results support the robustness of our models.

For our three models, the coefficient of risk disclosure has the expected sign. Risk disclosure has a positive effect on the credit rating. Banks with higher risk disclosure scores have better credit ratings. A greater level of risk disclosure can influence the CRA's opinion regarding the bank's ability to pays its financial obligations in full and on time. In addition, inversely, a higher credit rating can motivate a bank to enhance the risk disclosure in its annual reports. Our finding is in line with signaling theory and resource dependence theory. Indeed, according to these theories, an increasing level of risk disclosure can be important since it signals to CRAs the bank's performance and risk management practices. These may secure access to resources, and, in turn, improve the bank's credit rating. 
Our finding is consistent, also, with Bozanic and Kraft's (2014) finding that qualitative disclosures are associated with soft credit rating adjustments. These indicate that effective disclosures can justify favorable adjustments to credit ratings determined from using quantitative financial inputs. El Amer (2017) reports a positive relationship between banks' risk disclosure and their credit ratings and suggests that improved risk disclosure is a means through which managers reduce the information asymmetry and signal to the market, the bank's quality and its future prospects. Accordingly, these can facilitate its access to critical resources.

The results obtained from the ordered logit model show, also, that the number of blockholders has a negative effect on the credit rating. Banks with a larger number of blockholders have lower credit ratings. This finding is consistent with the findings of Bhojraj and Sengupta (2003) and Grassa (2015), who document that blockholders have an adverse impact on credit ratings. Skaife et al. (2006) explained that, as the most powerful shareholders, blockholders have an incentive to influence management to secure benefits that are detrimental to bondholders. Indeed, the concentration of ownership allows these blockholders to exercise excessive influence over management to protect benefits that are detrimental to the minority shareholders and the bondholders (Shleifer and Vishny, 1997; Bhojraj and Sengupta, 2003; Grassa 2015). Hence, as the number of blockholders increases, there is, in turn, a higher probability that these blockholders to use their influence to affect wealth transfers from bondholders and to influence such transfers to their benefit.

The coefficient, related to foreign ownership, correlates negatively and significantly to credit rating. Accordingly, foreign investors provide less control of management decisions and actions. Hence, bondholders face greater agency risk vis-a'-vis the management and, in turn, this leads to a weaker credit rating. Our finding is consistent with that of Grassa (2015).

The coefficients relating to the financial characteristics of the banks, which constitute our samples, have the expected signs. Consistent with previous research (Horrigan,1966; Skaife et al.2006; Kaplan and Urwitz,1979; Grassa 2015 and Oh and Park, 2017) and with the exception of those from model 3 , the results of the regression analysis document generally that there is a positive association between credit rating, bank size and bank profitability and that there is significantly negative association between credit rating and leverage at the $5 \%$ level. For the 
three models, there is, also, a significantly negative correlation between bank age and credit rating. In this respect, younger banks have higher credit ratings than older ones. Our results are contrary to Grassa's (2015) findings. We can explain this by the fact that, when compared to older banks, younger banks have well-organized management practices. These may secure access to resources and, in turn, improve the bank's credit rating. Moreover, unlike Grassa' (2015) finding, listed banks have lower credit ratings than non-listed banks. Listed banks are less efficient in monitoring their managements' management's opportunistic behaviors which disadvantage minority shareholders and bondholders.

Table 6 reports, also, that the Tier 1 ratio has a positive on a bank's credit rating. Banks with higher Tier 1 ratios have higher credit ratings. Moreover, GDP and Country disclosure index, which are employed as countries specific control variable, have positive effects on banks' credit ratings (except for Islamic banks on which these have no significant effects). Besides, when compared to conventional banks, Islamic banks have lower credit ratings.

Table 6a reports the comparison test of the coefficients in respect of the Islamic and conventional banks subsamples. Table 6a provides evidence that the risk disclosure's impact on credit rating is, as expected, stronger for Islamic banks than for conventional banks. Therefore, we accept Hypothesis 2.

\section{Robustness Tests:}

Insert Tables 7 and 8 here

As a robustness test, we divided the credit risk scores into the 8 subcategories that we used in the main regression. Table 7 shows that all subcategories of the risk disclosure score have significantly positive effects on the credit rating. The high effect is observed clearly for the Islamic banks' sample. Indeed, 7 of the 8 dimensions of risk disclosure affect the Islamic banks' credit ratings. However, for conventional banks, only 4 of the 8 dimensions affect the conventional 
banks' credit ratings. Our finding provides evidence that CRAs are more concerned with the Islamic banks' risk disclosure than with the conventional banks' risk disclosure. Due to the risk nature of the Islamic banking activities and when they are revising or making a new credit assessment of an Islamic bank, the CRAs place greater importance on risk disclosure in the Islamic banks' annual reports of and on the different categories of risk disclosure .

As another robustness test, Table 8 reports the results of estimating the logistic regression from using investment grade as the dependent variable whereby the investment grade is coded one if the bank's credit rating is BBB or better, and zero otherwise. The results are similar to those of the RATING analyses reported in Tables 6 and 7. For both the Islamic bank and the conventional bank subsamples, there is a significantly positive correlation between risk disclosure and investment grade.

\section{Conclusion:}

This paper has studied the impact of risk disclosure on the credit ratings of a sample of 169 banks over the period from 2009 to 2014. Our findings provide evidence that risk disclosure has a positive effect on credit ratings and when compared to conventional banks, Islamic banks have lower credit ratings. This is because, when compared to their conventional counterparts, they disclose less risk information. Moreover, the bank's leverage and the bank's age, foreign ownership and the number of blockholders, all have a negative effect on the bank's credit rating. However, Tier 1 ratio and country transparency index have positive effects on the bank's credit rating.

Our findings provide evidence that, when compared to banks with lower credit rating scores, banks with high credit rating scores are likely to be more transparent when it comes to risk disclosure level. Other things being equal, banks, which are evaluated highly in the market, provide more risk disclosure to investment companies and financial analysts beyond the authorized risk disclosure information and do so through the fair disclosure regulation. Moreover, the positive association between credit rating and risk disclosure is more pronounced for conventional banks than for Islamic banks. These results are generally robust when tested by different measurements of market expectations and risk disclosure. 
Our study offers several implications to policy makers and bank stakeholders. Understanding the factors, which influence credit ratings, and, more particularly, the inputs used by credit analysts, may help private and national rating agencies to adjust credit rating assessments and may help investors to gain better understandings of the ratings. These can provide insights into the means through which firms may access credit capital at lower cost. Consequently, our findings call for banks to improve the risk disclosure information in their annual reports since this can help to improve their credit ratings. Moreover, relevant stakeholders, policy makers, practitioners and the international and national CRAs must urge banks to improve the level of risk disclosure in their annual reports.

While the study offers comprehensive and interesting analysis of risk disclosure and credit ratings in the banking system, it suffers from some research limitations. First, due to the lack of literature on Islamic banks' risk disclosure and credit ratings, we experienced difficulties in deconstructing the conceptual framework for this study.

Second, the researchers acknowledge the limitation of data and, more especially, with respect to credit rating. Third, the scope of this study was limited since it focused on the effect of risk disclosure on the credit ratings of conventional and Islamic banks in 12 countries.

Notwithstanding these limitations, the research provides several important pieces of evidence that meet the research aims and objectives and provide answers to the research questions. Future studies should pay more attention to studying the different effects of risk disclosure in the banking sector generally and, more particularly, in relation to Islamic banks. Another avenue of future research is to focus on the benefits of risk disclosure to equity stakeholders by investigating the relationship between risk disclosure and the costs to banks of securing equity capital. 


\section{REFERENCES}

Abdallah, A. A.-N., Hassan, M. K., and McClelland, P. L. (2015). Islamic financial institutions, corporate governance, and corporate risk disclosure in Gulf Cooperation Council countries. Journal of Multinational Financial Management, 31, 63-82.

Abedifar, P., Molyneux, P., and Tarazi, A. (2018). Non-interest income and bank lending. Journal of Banking and Finance, 87, 411-426.

Abraham, S., and Cox, P. (2007). Analysing the Determinants of Narrative Risk Information in UK FTSE 100 Annual Reports. The British Accounting Review, 39, 227-248.

Adler, R. W., and Milne, M. J. (1999). Exploring the reliability of social and environmental disclosures content analysis. Accounting, Auditing and Accountability Journal, 12(2), 237256.

Afonso, A. (2003). Understanding the determinants of sovereign debt ratings: Evidence for the two leading agencies. Journal of Economics and Finance 27 (1), 56-74.

Ahmed, H., and Khan, T. (2007). Risk Management in Islamic Banking. In Handbook of Islamic Banking. Edward Elgar Publishing.

Alali, F., Anandarjan, A., and Jiang, W. (2012). The effect of corporate governance on firm's credit ratings: Further evidence using governance score in the United States. Accounting and Finance, 52(2), 291-312

Al-Hadi, A., Al-Yahyaee, K. H., Hussain, S. M., and Taylor, G. (2017). Market risk disclosures and corporate governance structure: Evidence from GCC financial firms. The Quarterly Review of Economics and Finance.

Aman, H., and Nguyen, P. (2013). Does good governance matter to debtholders? Evidence from the credit ratings of Japanese firms. Research in International Business and Finance, 29, 1434.

Amran, A., Bin, A. M. R., and Hassan, B. C. H. M. (2009). Risk reporting: An exploratory study on risk management disclosure in Malaysian annual reports. Managerial auditing journal, 24(1).

Ariffin, N., Archer, S. and Karim, R.A.A, (2009), "Risks in Islamic banks: Evidence from Empirical Research", Journal of Banking Regulation, Vol.10, 2, 153-163.

Ashbaugh-Skaife, H., Collins, D. W., and LaFond, R. (2006). The effects of corporate governance on firms' credit ratings. Journal of Accounting and Economics, 42(1-2), 203-243.

Barakat, A., and Hussainey, K. (2013). Bank governance, regulation, supervision, and risk reporting: Evidence from operational risk disclosures in European banks. International Review of Financial Analysis, 30, 254-273.

Basu, R., Naughton, J., and Wang, C. (2017). The Effect of Credit Rating Changes on Voluntary Disclosure. Working Paper

Beretta, S., and Bozzolan, S. (2004). A framework for the analysis of firm risk communication. The International Journal of Accounting, 39(3), 265-288. 
Bhojraj, S., and Sengupta, P. (2003). Effect of corporate governance on bond ratings and yields: The role of institutional investors and the outside directors. The Journal of Business, 76, 455475

Bonsall, S. B., and Miller, B. P. (2017). The impact of narrative disclosure readability on bond ratings and the cost of debt. Review of Accounting Studies, 22(2), 608-643.

Bozanic, Z., and Kraft, P. (2014). Qualitative Disclosure and Credit Analysts' Soft Rating Adjustments (SSRN Scholarly Paper No. ID 2962491). Rochester, NY

Bozanic, Z., Roulstone, D. T., and Van Buskirk, A. (2018). Management earnings forecasts and other forward-looking statements. Journal of Accounting and Economics, 65(1), 1-20.

Brown, S. V., and Tucker, J. W. (2011). Large-Sample Evidence on Firms' Year-over-Year MDandA Modifications. Journal of Accounting Research, 49(2), 309-346.

Brown, S. V., and Tucker, J. W. (2011). Large-Sample Evidence on Firms' Year-over-Year MDandA Modifications. Journal of Accounting Research, 49(2), 309-346.

Cabedo, J. D., and Tirado, J. M. (2004). The disclosure of risk in financial statements. Accounting Forum, 28(2), 181-200.

Campbell, D., and Loumioti, M. (2013). Monitoring and the Portability of Soft Information (SSRN Scholarly Paper No. ID 2233467). Rochester, NY.

Campbell, D., Loumioti, M., and Wittenberg Moerman, R. (2017). Making Sense of Soft Information: Interpretation Bias and Loan Quality (SSRN Scholarly Paper No. ID 2939881). Rochester, NY.

Cantor, R. M. and Packer, F. (1996) Determinants and Impact of Sovereign Credit Ratings. Economic Policy Review, Vol. 2, No. 2.

Cantor, R., and Packer, F. (1996). Determinants and Impact of Sovereign Credit Ratings (SSRN Scholarly Paper No. ID 1028774). Rochester, NY.

Chan, A. L.-C., Hsu, A. W., and Lee, E. (2013). Does Mandatory IFRS Adoption Affect the Credit Ratings of Foreign Firms Cross-Listed in the U.S.? Accounting Horizons, 27(3), 491-510.

Dar, M. R., Azeem, M., and Masood, D. O. (2013). Operational risk management, risk management approaches, and risk mitigation techniques: challenges faced by Islamic financial services. Journal of Business and Management, 11(2), 72-79.

DeBoskey, D., and Gillett, P. (2013). The impact of multi-dimensional corporate transparency on us firms' credit ratings and cost of capital. Review of Quantitative Finance and Accounting, 40(1), 101-134.

Deumes, R. (2008). Corporate Risk Reporting: A Content Analysis of Narrative Risk Disclosures in Prospectuses. The Journal of Business Communication (1973), 45(2), 120-157.

Dhaliwal, D. S., Li, O. Z., Tsang, A., and Yang, Y. G. (2011). Voluntary Nonfinancial Disclosure and the Cost of Equity Capital: The Initiation of Corporate Social Responsibility Reporting. The Accounting Review, 86(1), 59-100.

Dietrich, J. R., and Kaplan, R. S. (1982). Empirical Analysis of the Commercial Loan Classification Decision. The Accounting Review, 57(1), 18-38. 
Dignah, A., Latiff, R. A., and Rahman, A. A. (2012). Islamic banks' risk, profitability and risk disclosure. Afro-Asian J. of Finance and Accounting, 3(2), 105.

Dobler, M., Lajili, K., and Zéghal, D. (2011). Attributes of Corporate Risk Disclosure: An International Investigation in the Manufacturing Sector. Journal of International Accounting Research, 10(2), 1-22.

Elamer, A. A. M. (2017). Empirical essays on risk disclosures, multi-level governance, credit ratings, and bank value: evidence from MENA banks (doctoral). University of Huddersfield.

Elbannan, M. A. (2009). Quality of internal control over financial reporting, corporate governance and credit ratings. International Journal of Disclosure and Governance, 6(2), 127-149

Errico, L., and Farahbaksh, M. (1998). Islamic Banking: Issues in Prudential Regulations and Supervision (SSRN Scholarly Paper No. ID 882267). Rochester, NY

Frost, C. A. (2007). Credit Rating Agencies in Capital Markets: A Review of Research Evidence on Selected Criticisms of the Agencies. Journal of Accounting, Auditing and Finance, 22(3), 469-492.

Grassa, R. (2015). Corporate governance and credit rating in Islamic banks: Does Shariah $\mathrm{h}$ governance matters? Journal of Management and Governance, 1-32.

Grassa, R. and Chakroun, R. (2016). Ownership structure, board's characteristics and corporate governance disclosure in GCC banks: what about IBs?", International Journal of Accounting, Auditing and Performance Evaluation, Vol. 12 No. 4, pp. 360-395.

R Grassa, R Chakroun, K Hussainey (2019). Corporate governance and Islamic banks' products and services disclosure. Accounting Research Journal 31 (1), 75-89

Grassa R., Moumen N. and Husseiney k. (2019). What drives risk disclosure in Islamic and conventional banks? An international comparison. Working paper.

R Grassa, S El-Halaby, K Hussainey (2019). Corporate Governance and Multi-corporate Disclosures Evidence from Islamic Banks. Research in Corporate and Shariah Governance in the Muslim World: Theory and Practices.

Hayes, A. F., and Krippendorff, K. (2007). Answering the Call for a Standard Reliability Measure for Coding Data. Communication Methods and Measures, 1(1), 77-89.

He, G. (2018). Credit Ratings and Managerial Voluntary Disclosures. Financial Review, 53(2), $337-378$.

Hirtle, B. (2007). Public Disclosure, Risk, and Performance at Bank Holding Companies (SSRN Scholarly Paper No. ID 1003219). Rochester, NY.

Horrigan, J. (1966). The determinants of long-term credit standing with financial ratios. Journal of Accounting Research, 4, 44-62

Hussainey, K., and Elzahar, H. (2012). Determinants of narrative risk disclosures in UK interim reports. The Journal of Risk Finance, 13(2), 133-147.

Kaplan, R., and Urwitz, G. (1979). Statistical models of bond ratings: A methodological inquiry. Journal of Business, 52, 231-261. 
Kraft, P. (2015). Do rating agencies cater? Evidence from rating-based contracts. Journal of Accounting and Economics, 59(2), 264-283.

Krippendorff, K. (1980). Validity in Content Analysis. Computerstrategien für die Kommunikationsanalyse, 69-112.

Krippendorff, K. (2004). Reliability in Content Analysis. Human Communication Research, 30(3), 411-433.

Krippendorff, K. (2010). On Communicating: Otherness, Meaning, and Information. Routledge.

Kuang, Y. F., and Qin, B. (2013). Credit Ratings and CEO Risk-Taking Incentives. Contemporary Accounting Research, 30(4), 1524-1559.

Lev, B., and Penman, S. H. (1990). Voluntary Forecast Disclosure, Nondisclosure, and Stock Prices. Journal of Accounting Research, 28(1), 49-76.

Linsley, P. M., and Shrives, P. J. (2006). Risk reporting: A study of risk disclosures in the annual reports of UK companies. British Accounting Review, 38, 387-404.

Mayew, W. J., Sethuraman, M., and Venkatachalam, M. (2015). MDandA disclosure and the firm's ability to continue as a going concern. Accounting Review, 90(4), 1621-1651.

Moody's Special Comment. (1993) "Moody's Approach to the Credit Analysis of Banks and Bank Holding Companies," New York: Moody's Investors Service.

Morgan, D. P. (2002). Rating Banks: Risk and Uncertainty in an Opaque Industry. The American Economic Review, 92(4), 874-888.

Moumen, N., Ben Othman, H., and Hussainey, K. (2015). The value relevance of risk disclosure in annual reports: Evidence from MENA emerging markets. Research in International Business and Finance, 34(C), 177-204.

Moumen, N., Ben Othman, H., and Hussainey, K. (2016). Board structure and the informativeness of risk disclosure: Evidence from MENA emerging markets. Advances in Accounting, 35(C), 82-97.

Nahar, S., Azim, M., and Jubb, C. (2016). The determinants of risk disclosure by banking institutions: Evidence from Bangladesh. Asian Review of Accounting, 24(4), 426-444

Naughton R, Basu J.P. and Wang C., (2017) "The Effect of Credit Rating Changes on Voluntary Disclosure". Working Paper.

Nier, E., and Baumann, U. (2006). Market discipline, disclosure and moral hazard in banking. Journal of Financial Intermediation, 15(3), 332-361.

Oh, F. D., and Park, J. (2017). Credit ratings and corporate disclosure behaviour: evidence from regulation fair disclosure in Korea. Applied Economics, 49(35), 3481-3494.

Oliveira, J., Rodrigues, L. L., and Craig, R. (2011). Risk-related disclosure practices in the annual reports of Portuguese credit institutions: An exploratory study. Journal of Banking Regulation, 12(2), 100-118.

Packer, F., and Tarashev, N. (2011). Rating methodologies for banks. BIS Quarterly Review. 
Pérignon, C., and Smith, D. (2010). The level and quality of Value-at-Risk disclosure by commercial banks. Journal of Banking and Finance, 34(2), 362-377.

Radzi, R. M., and Lonik, K. A. T. (2016). Islamic Banks' Risks: It's Rating Methodology and Shariah Assessment Solutions. Journal of Islamic Banking and Finance, 4(2), 48-60.

Shleifer, A., and Vishny, R. W. (1997). A Survey of Corporate Governance. The Journal of Finance, 52(2), 737-783.

Skaife, A. H., Collins, D. W., and LaFond, R. (2006). The effects of corporate governance on firms' credit ratings. Journal of Accounting and Economics, 42, 203-243.

Standard and Poor's (2009). Corporate ratings criteria. http://www.standardandpoors.com

Stein, J. C. (2002). Information Production and Capital Allocation: Decentralized versus Hierarchical Firms. The Journal of Finance, 57(5), 1891-1921.

Weber, R. P. (1990). Basic content analysis. Sage Publications.

Welker, M. (1995). Disclosure Policy, Information Asymmetry, and Liquidity in Equity Markets. Contemporary Accounting Research, 11(2), 801-827. 


\section{Appendix}

Table 2A. Credit rating by sample

\begin{tabular}{|c|c|c|c|}
\hline Debt rating & All banks & Islamic banks & Conventional banks \\
\hline $\mathrm{Aaa}$ & 94 & 36 & 58 \\
\hline $\mathrm{Aa}$ & 72 & 21 & 51 \\
\hline $\mathrm{A}$ & 116 & 59 & 57 \\
\hline $\mathrm{Baa}$ & 201 & 93 & 52 \\
\hline $\mathrm{Ba}$ & 58 & 6 & 19 \\
\hline $\mathrm{B}$ & 19 & 0 & 5 \\
\hline $\mathrm{Caa} / \mathrm{Ca} / \mathrm{C}$ & 5 & 0 & \\
\hline
\end{tabular}

Table 2 B. Credit rating and average RD by country

\begin{tabular}{|c|c|c|c|}
\hline & & Average credit rating & Average $\mathrm{RD}$ \\
\hline \multirow[t]{2}{*}{ BAHRAIN } & Islamic Banks & 4.5 & 397 \\
\hline & Conventional Banks & 4.6 & 483.3 \\
\hline \multirow[t]{2}{*}{ EGYPT } & Islamic Banks & 3.0 & 245 \\
\hline & Conventional Banks & 4.0 & 383.4 \\
\hline \multirow[t]{2}{*}{ Jordan } & Islamic Banks & 3.7 & 358 \\
\hline & Conventional Banks & 4.0 & 492.3 \\
\hline \multirow[t]{2}{*}{ Saudi Arabia } & Islamic Banks & 4.9 & 419.7 \\
\hline & Conventional Banks & 5.5 & 478.1 \\
\hline \multirow[t]{2}{*}{ Kuwait } & Islamic Banks & 5.2 & 454 \\
\hline & Conventional Banks & 5.9 & 478.9 \\
\hline \multirow[t]{2}{*}{ Malaysia } & Islamic Banks & 6.2 & 620 \\
\hline & Conventional Banks & 5.9 & 536.6 \\
\hline \multirow[t]{2}{*}{ Pakistan } & Islamic Banks & 3.6 & 305 \\
\hline & Conventional Banks & 4.0 & 367.1 \\
\hline \multirow[t]{2}{*}{ Qatar } & Islamic Banks & 4.7 & 411.8 \\
\hline & Conventional Banks & 5.9 & 464.3 \\
\hline \multirow[t]{2}{*}{ Tunisia } & Islamic Banks & Not rated & 110 \\
\hline & Conventional Banks & 4.0 & 94 \\
\hline \multirow[t]{2}{*}{ Turkey } & Islamic Banks & 4.3 & 563.2 \\
\hline & Conventional Banks & 4 & 561.7 \\
\hline \multirow[t]{2}{*}{ UAE } & Islamic Banks & 4.4 & 476.8 \\
\hline & Conventional Banks & 5.1 & 610 \\
\hline \multirow[t]{2}{*}{ Oman } & Islamic Banks & Not rated & 219 \\
\hline & Conventional Banks & 3.6 & 329 \\
\hline
\end{tabular}


Table 3: Descriptive statistics for average RD by credit rating category.

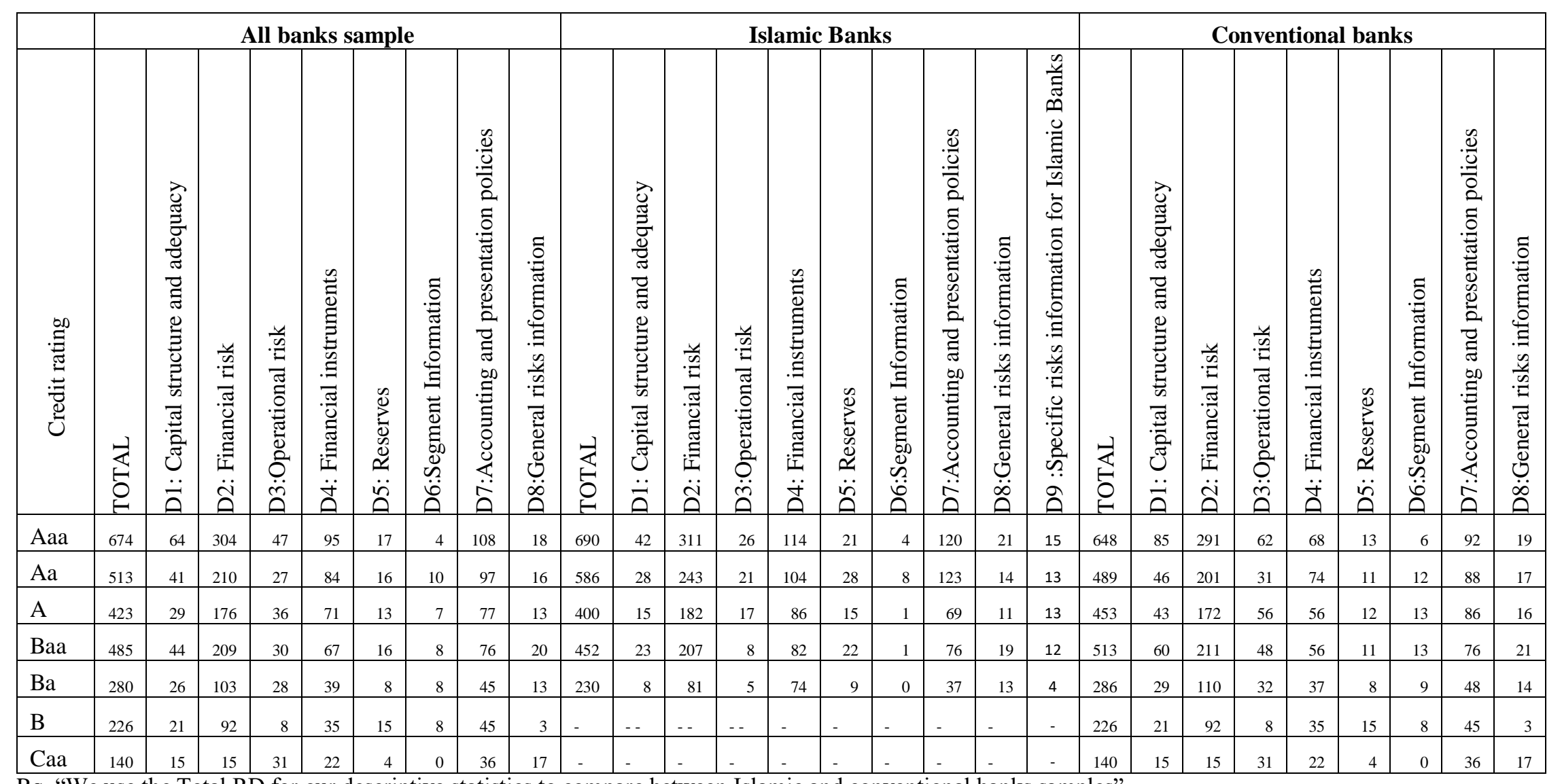

Rq. "We use the Total RD for our descriptive statistics to compare between Islamic and conventional banks samples" 


\section{Table 4: Descriptive statistics}

\begin{tabular}{|c|c|c|c|c|c|c|c|c|c|c|c|c|c|c|c|c|}
\hline & \multicolumn{5}{|c|}{ All Banks sample } & \multicolumn{5}{|c|}{ Islamic Banks sample } & \multicolumn{5}{|c|}{ conventional Banks sample } & \multirow[t]{2}{*}{ t-test } \\
\hline & mean & median & $\begin{array}{l}\text { std. } \\
\text { dev }\end{array}$ & Min & Max & mean & median & $\begin{array}{l}\text { std. } \\
\text { dev }\end{array}$ & Min & Max & mean & median & $\begin{array}{l}\text { std. } \\
\text { dev }\end{array}$ & Min & Max & \\
\hline Rating & 4.76 & 4 & 1.4 & 1 & 7 & 4.94 & 5 & 1.15 & 3 & 7 & 4.66 & 4 & 1.52 & 1 & 7 & $0.001 * * *$ \\
\hline RD & 438 & 407 & 235 & 7 & 1684 & 437 & 401 & 232 & 7 & 1684 & 442 & 415 & 228 & 14 & 1296 & $0.000 * * *$ \\
\hline ROA & 0.02 & 0.01 & 0.04 & -0.15 & 0.52 & 0.02 & 0.01 & 0.06 & -0.15 & 0.52 & 0.02 & 0.02 & 0.02 & -0.04 & 0.16 & 0.897 \\
\hline LIST & 0.54 & 1 & 0.5 & & & 0.46 & 0 & 0.05 & & & 0.6 & 1 & 0.49 & & & $0.011 * *$ \\
\hline BKAGE & 31.2 & 30 & 25.16 & 3 & 150 & 18.43 & 12 & 15.84 & 3 & 61 & 40.61 & 35 & 26.75 & 3 & 150 & $0.00 * * *$ \\
\hline LEVERAGE & 0.64 & 0.66 & 0.2 & 0 & 1.42 & 0.63 & 0.67 & 0.23 & 0.01 & 0.94 & 0.53 & 0.65 & 0.17 & 0.21 & 0.93 & 0.254 \\
\hline FOREIGN & 0.38 & 0.15 & 0.42 & 0 & 1 & 0.49 & 0.49 & 0.46 & 0 & 1 & 0.26 & 0.1 & 0.34 & 0 & 1 & $0.000 * *$ \\
\hline BLOCK & 2.54 & 2 & 1.76 & 0 & 7 & 2.25 & 1 & 1.64 & 1 & 7 & 2.86 & 3 & 1.81 & 1 & 7 & 0.654 \\
\hline TIER 1 & 0.32 & 0.17 & 1.05 & 0.03 & 0.92 & 0.24 & 0.19 & 0.17 & 0.01 & 0.92 & 0.17 & 0.16 & 0.03 & 0.08 & 0.26 & $0.000 * * *$ \\
\hline COUTRANSDEX & 7.09 & 8 & 2.32 & 4 & 10 & 7.52 & 8 & 2.13 & 4 & 10 & 6.83 & 8 & 2.39 & 4 & 10 & \\
\hline
\end{tabular}

T-test: Mean comparison test

$*, * *$, and $* * *$ indicate significance at $10 \%, 5 \%$, and $1 \%$ level.

RD: risk disclosure score; ROA: Net income/ total assets; LIST: 1 if the bank is listed in the stock exchange, 0 otherwise; BANKSIZE: Natural logarithm of total assets; BKAGE: Number of years; LEVERAGE: Long-term debt/ total assets; FOREIGN: Percent of shares owned by foreign shareholders; TIER 1: Tier 1 ratio; GDP: Natural logarithm of Gross domestic products; COUTRANSDEX: The index ranges from 0 to 10 , with higher values indicating more disclosure.; Islamic: 1 if it's an Islamic banks, 0 Otherwise 


\section{Table 5: Correlation Matrix}

\begin{tabular}{|c|c|c|c|c|c|c|c|c|c|c|c|}
\hline & $\mathrm{RD}$ & ROA & LIST & BANKSIZE & BKAGE & LEVERAGE & FOREIGN & BLOCK & TIER 1 & GDP & $\begin{array}{l}\text { COUTRANSDE } \\
\mathrm{X}\end{array}$ \\
\hline $\mathrm{RD}$ & 1.00 & & & & & & & & & & \\
\hline \multirow[t]{2}{*}{ ROA } & -0.05 & 1.00 & & & & & & & & & \\
\hline & $(0.26)$ & & & & & & & & & & \\
\hline \multirow[t]{2}{*}{ LIST } & -0.01 & 0.05 & 1.00 & & & & & & & & \\
\hline & $(0.83)$ & $(0.31)$ & & & & & & & & & \\
\hline \multirow[t]{2}{*}{ BANKSIZE } & 0.33 & -0.01 & -0.08 & 1.00 & & & & & & & \\
\hline & $(0.00)^{* * * *}$ & $(0.80)$ & $(0.10)^{*}$ & & & & & & & & \\
\hline \multirow[t]{2}{*}{ BKAGE } & 0.10 & 0.02 & 0.09 & 0.02 & 1.00 & & & & & & \\
\hline & $(0.01)^{* * * *}$ & $(0.69)$ & $(0.02) * *$ & $(0.73)$ & & & & & & & \\
\hline \multirow[t]{2}{*}{ LEVERAGE } & 0.09 & 0.06 & 0.28 & -0.07 & 0.00 & 1.00 & & & & & \\
\hline & $(0.05)^{* * *}$ & $(0.22)$ & $(0.00)^{* * * *}$ & $(0.13)$ & $(0.96)$ & & & & & & \\
\hline \multirow[t]{2}{*}{ FOREIGN } & -0.02 & 0.04 & -0.55 & 0.06 & -0.37 & -0.26 & 1.00 & & & & \\
\hline & $(0.68)$ & $(0.45)$ & $(\mathbf{0 . 0 0})^{* * * *}$ & $(0.18)$ & $(\mathbf{0 . 0 0})^{* * * *}$ & $(0.00)^{* * *}$ & & & & & \\
\hline \multirow[t]{2}{*}{ BLOCK } & -0.14 & -0.06 & 0.05 & 0.01 & 0.08 & -0.01 & -0.25 & 1.00 & & & \\
\hline & $(\mathbf{0 . 0 0})^{* * * *}$ & $(0.22)$ & $(0.00)^{* * * *}$ & $(0.76)$ & $(0.08) *$ & $(0.02)^{* *}$ & $(0.00)^{* * * *}$ & & & & \\
\hline \multirow[t]{2}{*}{ TIER 1} & 0.17 & 0.03 & -0.20 & -0.29 & -0.27 & -0.24 & 0.22 & 0.18 & 1.00 & & \\
\hline & $(\mathbf{0 . 0 0})^{* * * *}$ & $(0.23)$ & $(0.00)^{* * *}$ & $(\mathbf{0 . 0 0})^{* * * *}$ & $(\mathbf{0 . 0 0})^{* * * *}$ & $(\mathbf{0 . 0 0})^{* * * *}$ & $(\mathbf{0 . 0 0}) * * *$ & $(\mathbf{0 . 0 0}) * * *$ & & & \\
\hline \multirow[t]{2}{*}{ GDP } & 0.03 & 0.41 & 0.03 & -0.02 & -0.05 & 0.04 & -0.07 & -0.08 & 0.03 & 1.00 & \\
\hline & $(0.36)$ & $(0.37)$ & $(0.44)$ & $(0.72)$ & $(0.16)$ & $(0.44)$ & $(0.12)$ & $(0.08)^{*}$ & $(0.51)$ & & \\
\hline \multirow[t]{2}{*}{ COUTRANSDEX } & 0.32 & -0.03 & -0.34 & -0.08 & -0.02 & 0.07 & 0.38 & -0.18 & 0.03 & 0.14 & 1.00 \\
\hline & $(\mathbf{0 . 0 0})^{* * * *}$ & $(0.46)$ & $(\mathbf{0 . 0 0})^{* * * *}$ & $(0.07)^{*}$ & $(0.50)$ & $(0.14)$ & $(\mathbf{0 . 0 0})^{* * * *}$ & $(0.00)^{* * * *}$ & $(0.65)$ & $(\mathbf{0 . 0 0})^{* * * *}$ & \\
\hline
\end{tabular}

$*, * *$, and *** indicate significance at $10 \%, 5 \%$, and $1 \%$ level. P-value between parentheses.

RD: risk disclosure score; ROA: Net income/ total assets; LIST: 1 if the bank is listed in the stock exchange, 0 otherwise; B ANKSIZE: Natural logarithm of total assets; BKAGE: Number of years; LEVERAGE: Long-term debt/ total assets; FOREIGN: Percent of shares owned by foreign shareholders; TIER 1: Tier 1 ratio; GDP: Natural logarithm of Gross domestic products; COUTRANSDEX: The index ranges from 0 to 10, with higher values indicating more disclosure.; Islamic: 1 if it's an Islamic banks, 0 Otherwise 


\section{Table 6: regression results}

\begin{tabular}{|c|c|c|c|c|c|c|c|c|c|}
\hline & \multicolumn{3}{|c|}{ Model 1: ALL BANKS SAMPLE } & \multicolumn{3}{|c|}{ Model 2: ISLAMIC BANKS SAMPLE } & \multicolumn{3}{|c|}{ Model 3: CONVENTIONAL BANKS SAMPLE } \\
\hline & Coef & t-student & P-value & Coef & t-student & P-value & Coef & t-student & P-value \\
\hline $\mathrm{RD}$ & $\mathbf{0 . 0 2}$ & 4.27 & $0.00^{* * * *}$ & $\mathbf{0 . 0 3}$ & 3.12 & $0.002 * * *$ & 0.09 & 2.01 & $\mathbf{0 . 0 7 *}$ \\
\hline ROA & 9.05 & 2.01 & $0.045^{* *}$ & 0.641 & 2.16 & $0.056 *$ & $\mathbf{0 . 2 3}$ & 1.9 & $0.058 *$ \\
\hline LIST & -0.39 & -1.66 & $0.097 *$ & -2.13 & -4.23 & $0.00^{* * * *}$ & 0.457 & 0.86 & 0.404 \\
\hline BANKSIZE & 0.56 & 5.38 & $0.00 * * *$ & 1.47 & 6.15 & $0.00 * * *$ & 0.159 & 1.12 & 0.263 \\
\hline BKAGE & -0.026 & -4.56 & $0.00 * * *$ & -0.039 & -2.66 & $0.008 * * *$ & -0.033 & -4.64 & $0.00 * * *$ \\
\hline LEVERAGE & -0.284 & 0.37 & $0.048 * *$ & -3.38 & -2.89 & $0.004 * * *$ & -0.876 & 0.74 & 0.46 \\
\hline FOREIGN & -0.07 & 0.19 & $0.052 *$ & -0.89 & 1.96 & $0.05 * *$ & -1.21 & 1.68 & $\mathbf{0 . 0 7} *$ \\
\hline BLOCK & -0.31 & 4.24 & $0.00^{* * * *}$ & -0.42 & -4.21 & $\mathbf{0 . 0 0}$ *** & -0.473 & -4.59 & $0.00 * * *$ \\
\hline TIER 1 & 2.23 & 1.69 & $0.091 *$ & 4.916 & 2.77 & $0.006 * * *$ & 3.221 & 1.75 & $0.057 *$ \\
\hline GDP & 6.08 & 2.32 & $0.02 * *$ & 3.808 & 0.75 & 0.453 & 3.72 & 1.1 & 0.271 \\
\hline COUTRANSDEX & 0.089 & 1.76 & $0.076 *$ & -0.106 & -0.97 & 0.331 & 0.256 & 3.37 & $0.00 * * *$ \\
\hline Islamic & -0.644 & -2.43 & $0.015 * *$ & & & & & & \\
\hline Lr chi2 & & 107.98 & & & 96.63 & & & 78.35 & \\
\hline Prob chi 2 & & $0.00 * * *$ & & & $0.00 * * *$ & & & $0.00 * * *$ & \\
\hline Pseudo R ${ }^{2}$ & & 0.4298 & & & 0.3491 & & & 0.4436 & \\
\hline log likelihood & & 437.222 & & & 145.6223 & & & 233.67 & \\
\hline
\end{tabular}

$*, * *$, and *** indicate significance at $10 \%, 5 \%$, and $1 \%$ level.

RD: risk disclosure score; ROA: Net income/ total assets; LIST: 1 if the bank is listed in the stock exchange, 0 otherwise; B ANKSIZE: Natural logarithm of total assets; BKAGE: Number of years; LEVERAGE: Long-term debt/ total assets; FOREIGN: Percent of shares owned by foreign shareholders; TIER 1: Tier 1 ratio; GDP: Natural logarithm of Gross domestic products; COUTRANSDEX: The index ranges from 0 to 10, with higher values indicating more disclosure.; Islamic: 1 if it's an Islamic banks, 0 Otherwise 
Table 6.a. Marginal effect results

\begin{tabular}{|c|c|c|c|c|c|}
\hline & & Margin & $\begin{array}{l}\text { Delta-method } \\
\text { Std. Err. }\end{array}$ & $\mathrm{z}$ & $P>|z|$ \\
\hline Model 1: ALL BANKS SAMPLE & $\mathrm{RD}$ & 0.370 & 0.073 & 3.65 & $0.000 * * *$ \\
\hline Model 2: ISLAMIC BANKS SAMPLE & RD & 0.244 & 0.043 & 2.87 & $0.000 * * *$ \\
\hline Model 3: CONVENTIONAL BANKS SAMPLE & RD & 0.318 & 0.057 & 2.33 & $0.000 * * *$ \\
\hline
\end{tabular}

Table 6.b: Coefficient comparison test between Islamic and conventional banks subsamples:

\begin{tabular}{|l|l|}
\hline Chi2(1) & 42.04 \\
\hline Prob > chi2 & $0.000 * * *$ \\
\hline$*, * *$, and $* * *$ indicate significance at $10 \%, 5 \%$, and $1 \%$ level.
\end{tabular}


Table 7: Robustness Test

\begin{tabular}{|c|c|c|c|c|c|c|c|c|c|}
\hline & \multicolumn{3}{|c|}{$\begin{array}{c}\text { Model 1: ALL BANKS } \\
\text { SAMPLE }\end{array}$} & \multicolumn{3}{|c|}{$\begin{array}{c}\text { Model 2: ISLAMIC BANKS } \\
\text { SAMPLE }\end{array}$} & \multicolumn{3}{|c|}{$\begin{array}{l}\text { Model 3: CONVENTIONAL BANKS } \\
\text { SAMPLE }\end{array}$} \\
\hline & Coef & t-student & P-value & Coef & t-student & $\mathrm{P}$-value & Coef & t-student & $\mathrm{P}$-value \\
\hline D1 & 0.07 & 1.27 & $0.07 *$ & 0.09 & 3.09 & $0.002 * * *$ & 0.01 & 1.97 & $0.049 * *$ \\
\hline $\mathrm{D} 2$ & 0.02 & 1.63 & $0.01 * * *$ & 0.007 & 1.78 & 0.074* & 0.006 & 0.25 & 0.806 \\
\hline D3 & 0.009 & 1.6 & 0.10* & 0.006 & 0.47 & 0.64 & 0.02 & 2.08 & $0.037 * *$ \\
\hline D4 & 0.007 & 2.44 & $0.015 * *$ & 0.011 & 2.21 & $0.027 * *$ & 0.04 & 0.61 & 0.54 \\
\hline D5 & 0.027 & 3.88 & $0.00 * * *$ & 0.06 & 4.79 & $0.00 * * *$ & 0.046 & 1.68 & 0.093* \\
\hline D6 & 0.04 & 2.51 & $0.01 * * *$ & 0.36 & 6.7 & $0.00 * * *$ & 0.056 & 3.04 & $0.002 * * *$ \\
\hline D7 & 0.09 & 2.65 & $0.01 * * *$ & 0.039 & 3.98 & $0.00 * * *$ & 0.08 & 1.3 & 0.196 \\
\hline D8 & 0.02 & 1.97 & $0.049 * *$ & 0.055 & 2.36 & $0.00 * * *$ & 0.008 & 0.65 & 0.516 \\
\hline ROA & -7.46 & -1.67 & 0.096 & 2.25 & 0.27 & 0.788 & -29.25 & 2.23 & $0.026 * *$ \\
\hline LIST & -0.49 & -1.53 & 0.127 & -2.029 & 2.97 & $0.003 * * *$ & 0.72 & 1.21 & 0.225 \\
\hline BANKSIZE & 0.73 & 6.67 & $0.00 * * *$ & 2.56 & 6.87 & $0.001 * * *$ & 0.43 & 2.57 & $0.01 * * *$ \\
\hline BKAGE & -0.016 & 2.73 & $0.006 * * *$ & $-\mathbf{0 . 0 5 7}$ & -2.75 & $0.01 * * *$ & -0.03 & 4.17 & $0.01 * * *$ \\
\hline LEVERAGE & 0.801 & 1.04 & 0.161 & -5.91 & -3.34 & $0.001 * * *$ & 0.71 & 0.56 & 0.57 \\
\hline FOREIGN & -0.534 & 1.63 & $0.10 *$ & -3.68 & 4.86 & $0.000 * * *$ & -0.63 & 0.77 & 0.443 \\
\hline BLOCK & -0.294 & -3.99 & $0.00 * * *$ & -0.356 & 4.36 & $0.00 * * *$ & -0.378 & 3.37 & $0.01 * * *$ \\
\hline TIER 1 & 2.79 & 1.93 & $0.05 * *$ & 7.236 & 2.93 & $0.003 * * *$ & -3.81 & 0.67 & 0.502 \\
\hline GDP & 7.801 & 2.89 & $0.004 * * *$ & 2.98 & 0.5 & 0.615 & 3.485 & 0.99 & 0.323 \\
\hline COUTRANSDEX & 0.081 & 1.4 & 0.161 & 0.031 & 0.21 & 0.843 & 0.238 & 2.93 & $0.003 * * *$ \\
\hline Islamic & -0.666 & 1.97 & 0.096* & & & & & & \\
\hline Lr chi2 & & 154.17 & & & 187.47 & & 96.99 & & \\
\hline Prob chi 2 & & $0.000 * * *$ & & & $0.000 * * *$ & & $0.000 * * *$ & & \\
\hline pseudo r2 & & 0.3549 & & & 0.483 & & 0.2742 & & \\
\hline log likelihood & & 420.56 & & & 100.206 & & 229.92 & & \\
\hline
\end{tabular}

$*, * *$, and $* * *$ indicate significance at $10 \%, 5 \%$, and $1 \%$ level respectively. 
D1: Capital structure and adequacy; D2: Financial risk; D3:Operational risk; D4: Financial instruments; D5: Reserves; D6:Segment Information; D7:Accounting and presentation policies; D8:General risks information; ROA: Net income/ total assets; LIST: 1 if the bank is listed in the stock exchange, 0 otherwise; BANKSIZE: Natural logarithm of total assets; BKAGE: Number of years; LEVERAGE: Long-term debt/ total assets; FOREIGN: Percent of shares owned by foreign shareholders; TIER 1: Tier 1 ratio; GDP: Natural logarithm of Gross domestic products; COUTRANSDEX: The index ranges from 0 to 10, with higher values indicating more disclosure.; Islamic: 1 if it's an Islamic banks, 0 Otherwise

\section{Table 7.a: Coefficient comparison test between Islamic and conventional banks subsamples:}

\begin{tabular}{|c|c|}
\hline Chi2(1) & 102.02 \\
\hline Prob > chi2 & $0.000 * * *$ \\
\hline
\end{tabular}


Table 8: Robustness Test: Investment grade regression

\begin{tabular}{|c|c|c|c|c|c|c|c|c|c|}
\hline & \multicolumn{3}{|c|}{ All sample } & \multicolumn{3}{|c|}{ Islamic banks sample } & \multicolumn{3}{|c|}{ Conventional banks sample } \\
\hline & Coef & t-student & P-value & Coef & t-student & P-value & Coef & t-student & P-value \\
\hline $\mathrm{RD}$ & 0.018 & 2.25 & $0.025 * *$ & 0.03 & 3.22 & $0.002 * * *$ & 0.121 & 2.56 & $0.050^{*}$ \\
\hline ROA & -15.27 & -0.52 & 0.603 & 0.641 & 2.36 & $0.056 *$ & 0.243 & 2.1 & $0.053 *$ \\
\hline LIST & -1.56 & -1.09 & 0.274 & -2.13 & -4.23 & $0.000 * * *$ & 0.683 & 1.25 & 0.304 \\
\hline BANKSIZE & 0.766 & 1.68 & $0.092^{*}$ & 1.47 & 6.15 & $0.000 * * *$ & 0.298 & 1.68 & $0.100 *$ \\
\hline BKAGE & 0.104 & 2.03 & $0.043 * *$ & -0.039 & -2.66 & $0.008 * * *$ & -0.124 & -4.87 & $0.000 * * *$ \\
\hline LEVERAGE & -3.72 & 2.5 & $0.012 * *$ & -3.38 & -3.01 & $0.004 * * *$ & -0.577 & 1.45 & 0.221 \\
\hline FOREIGN & -1.352 & 2.42 & $0.016 * *$ & -0.89 & 1.97 & $0.05^{* *}$ & -1.232 & 1.78 & $0.050 *$ \\
\hline BLOCK & -0.49 & 1.68 & 0.09* & -0.42 & -4.21 & $0.000 * * *$ & -0.473 & -4.59 & $\mathbf{0 . 0 0 0} * * *$ \\
\hline TIER 1 & -4.28 & -0.26 & 0.792 & 4.916 & 2.77 & $0.006 * * *$ & 3.221 & 1.75 & $0.057 *$ \\
\hline GDP & 1.96 & 1.66 & $0.09 *$ & 3.808 & 0.55 & 0.453 & 3.85 & 1.52 & 0.112 \\
\hline COUTRANSDEX & -0.134 & 0.39 & 0.694 & -0.106 & -0.96 & 0.331 & 0.179 & 3.46 & $0.000 * * *$ \\
\hline Lr chi2 & & 90.62 & & & 97.43 & & & 78.35 & \\
\hline prb chi2 & & $0.000 * * *$ & & & $0.000 * * *$ & & & $0.000 * * *$ & \\
\hline pseudo r2 & & 0.7204 & & & 0.3639 & & & 0.4436 & \\
\hline log likelihood & & 17.58 & & & 146.78 & & & 229.92 & \\
\hline
\end{tabular}

$*, * *$, and $* * *$ indicate significance at $10 \%, 5 \%$, and $1 \%$ level.

RD: risk disclosure score; ROA: Net income/ total assets; LIST: 1 if the bank is listed in the stock exchange, 0 otherwise; BANKSIZE: Natural logarithm of total assets; BKAGE: Number of years; LEVERAGE: Long-term debt/ total assets; FOREIGN: Percent of shares owned by foreign shareholders; TIER 1: Tier 1 ratio; GDP: Natural logarithm of Gross domestic products; COUTRANSDEX: The index ranges from 0 to 10 , with higher values indicating more disclosure. 
Table 8.a. Marginal effect results

\begin{tabular}{|c|c|c|c|c|c|}
\hline & & Margin & $\begin{array}{l}\text { Delta-method } \\
\text { Std. Err. }\end{array}$ & $z$ & $P>|z|$ \\
\hline Model 1: ALL BANKS SAMPLE & $\mathrm{RD}$ & 0.412 & 0.065 & 2.56 & $0.000 * * *$ \\
\hline Model 2: ISLAMIC BANKS SAMPLE & $\mathrm{RD}$ & 0.319 & 0.059 & 3.12 & $0.000 * * *$ \\
\hline Model 3: CONVENTIONAL BANKS SAMPLE & $\mathrm{RD}$ & 0.401 & 0.049 & 2.71 & $0.000 * * *$ \\
\hline
\end{tabular}

$*, * *$, and $* * *$ indicate significance at $10 \%, 5 \%$, and $1 \%$ level.

Table 8.b: Coefficient comparison test between Islamic and conventional banks subsamples:

\begin{tabular}{|c|c|}
\hline Chi2(1) & 48.02 \\
\hline Prob > chi2 & $0.000 * * *$ \\
\hline
\end{tabular}




\section{Appendix A: Risk disclosure index}

\begin{tabular}{|c|c|}
\hline & Capital structure and adequacy \\
\hline 1 & Capital structure \\
\hline 2 & Changes in capital structure \\
\hline 3 & Capital instruments \\
\hline 4 & Capital adequacy - tier $1 \& 2$ capital and ratios \\
\hline 5 & Equity Risk \\
\hline 6 & Contingency planning \\
\hline 7 & Capital management strategy \\
\hline \multirow[t]{2}{*}{8} & Future capital plans \\
\hline & Financial risk \\
\hline 9 & Pricing Risk \\
\hline 10 & Liquidity \\
\hline 11 & Credit \\
\hline 12 & Changes in Interest Rates \\
\hline 13 & Credit Risk Exposure \\
\hline 14 & Insurance Risk \\
\hline 15 & Market Risk \\
\hline 16 & Interest Rate \\
\hline 17 & Exchange Rate \\
\hline \multirow[t]{2}{*}{18} & Sensitivity Analysis \\
\hline & Operational risk \\
\hline 19 & Operational risk management \\
\hline 20 & Operational value-at-risk (VaR/economic capital/Pillar 2 capital) \\
\hline 21 & Internal audit function/ \\
\hline 22 & Internal control system \\
\hline 23 & Business Disruption and Systems Failures \\
\hline 24 & Legal risks \\
\hline 25 & Compliance risk \\
\hline 26 & Fraud risk (internal/external) \\
\hline 27 & Damage to Physical Assets \\
\hline \multirow[t]{2}{*}{28} & Employment Practices and Workplace Safety \\
\hline & Financial instruments \\
\hline 29 & Derivatives \\
\hline 30 & Fair value \\
\hline 31 & Cumulative change in Fair value \\
\hline 32 & Hedging Description \\
\hline \multirow[t]{2}{*}{33} & Cash flow Hedge \\
\hline & Reserves \\
\hline 34 & Reserves \\
\hline
\end{tabular}




\begin{tabular}{|r|l|}
\hline 35 & Statutory Reserves \\
\hline 36 & Legal Reserves \\
\hline 37 & Segment Information \\
\hline 38 & Customer Concentration \\
\hline & Accounting and presentation policies \\
\hline 39 & Risk Management \\
\hline 40 & Objective of Holding Derivatives \\
\hline 41 & Estimates \\
\hline 42 & Collateral Assets \\
\hline 43 & Financial Assets Impairment \\
\hline 44 & Assets Impairment \\
\hline 45 & Contingent Liabilities \\
\hline 46 & Contingent Assets \\
\hline 47 & Lower of Cost or Market \\
\hline 48 & Contingency \\
\hline & General risks information \\
\hline 49 & Concentration of Credit Risk \\
\hline 50 & Customer Satisfaction \\
\hline 51 & High Competition \\
\hline 52 & Commodity \\
\hline 53 & Natural Disasters \\
\hline 54 & Communications \\
\hline 55 & Outsourcing \\
\hline 56 & Reputation \\
\hline 57 & Competition \\
\hline 58 & Weather Conditions \\
\hline 59 & Change in Technology \\
\hline & Specific risks information for Islamic Banks \\
\hline 60 & Rate of return risk \\
\hline 61 & Shariah non-compliance risk \\
\hline 62 & Displaced commercial risk \\
\hline 63 & Equity investment risk \\
\hline 64 & Inventory risk \\
\hline 65 & Market risk \\
\hline 66 & Fiduciary risk \\
\hline 68 & PER \\
\hline 69 & IRR \\
\hline & \\
\hline
\end{tabular}

